\title{
Die Reformatoriese kerkbegrip: Enkele groot lyne op grond van Calvyn se uiteensetting
}

\author{
A D Pont \\ Universiteit van Pretoria \\ Emeritus-professor
}

\begin{abstract}
Reformed ecclesiology: A few major tenets based on Calvin

Reformed ecclesiology is not a closed system. Notwithstanding differences, there is however a remarkable consensus on the major tenets of the doctrine of the church. An outline - mainly of Calvin's view - is given in the article, and the following arguments are brought forward: Jesus Christ is the only head of his body, which is a covenant community. The church is seen as a community sui generis, confessing its union with Christ and living its faith in the world.
\end{abstract}

\section{INLEIDING}

Die woord kerkbegrip dui onmiddellik op 'n bepaalde problematiek wanneer daar oor die kerk by die reformatoriese vadere gehandel word. Die vraag is of dit gaan oor die kerk as 'n geloofsartikel of oor die kerk as die 'uiterlike hulp- en ondersteuningsmiddel waardeur God ons tot die gemeenskap met Christus uitnooi en ons daarin hou' (Inst 4.1.1). Dit moet egter gestel word dat daar 'n duidelike verband bestaan tussen die kerk van die geloof en die georganiseerde, sigbare kerk. Albei is werklikhede want Petrus verwys na Jesus as die hemelse Herder en Biskop (1 Pet 2:25) en in Johannes se Openbaring word gepraat van die vier en twintig ouderlinge wat voor die Lam neerbuig (Op 4:4, 10). Die aardse instituut of organisasie is kerk omdat daar 'n verband met die kerk van die geloof is.

As die leer oor die kerk by die reformatore nagegaan word, blyk dit dat die ekklesiologie nie 'n geslote leerstuk vorm nie. Daaroor bestaan nie dieselfde dogmatiese presiesheid soos oor die Godsleer of die Christologie nie. Dit is te verstane, want die kerk staan nie in die sentrum van die geloofsbelydenis nie. Tog het die reformatore die band tussen die kerk van die geloof en die kerk as organisatoriese struktuur vasgehou en daarom ook ' $n$ leer aangaande die kerk in die geloofsbelydenis gehad en dit verbind met die kerkorde (Noordmans 1984:421). 
Die kerkbegrip van die reformatoriese vadere wat vir die denke in ons kerklike tradisie en wêreld rigtinggewend is, is nog steeds dié van Calvyn. Sy verstaan van die Skrif en sy verklaring daarvan na die reël van die geloof, het 'n merkwaardige blywende vermoë wat nie vanselfsprekend is in die werk van 'n mens nie (Noordmans 1984:395). Dit werk nogal irriterend op diegene wat slawe geword het van die idee van vooruitgang of progressie. In die kerk is die verlede en die toekoms egter dimensies van die hede sodat die verlede nooit as ' $n$ voltooide verbygegane waardeer word nie. Noordmans maak die opmerking:

Reeds de onderscheiding tusschen gisteren, vandaag en morgen eist een mystiek vermogen. Augustinus, Kierkegaard en Heidegger zijn daar om ons dat te zeggen. Wie meent dat de 'kerkvader van de negentiende eeuw', Schleiermacher, ons in de twintigste eeuw nader is dan Calvijn in de zestiende of zelfs Augustinus in de vijfde, heeft de ogen niet goed open.

(Noordmans 1984:501)

In die sestiende eeu het, soos bekend, twee groot vrae die teologie beheers. Dit was enersyds die vraag na die regverdige, genadige God en andersyds die vraag na die ware kerk. Die twee vrae het direk met mekaar saamgehang en dit is opvallend as Calvyn daarop ingaan met watter versigtigheid en eerbied hy oor God skryf en oor die Waarheid wat God in sy Skrifte aan ons gee (Inst 1.13.3). Calvyn wou in al sy werk niks méér sê as wat die Skrif self sê nie. Daarby het hy 'n duidelike besef van die lewende God wat deur sy Woord en Gees aktief besig is in sy kerk en in die geskiedenis van die mens.

Wanneer Calvyn die vraag na die ware kerk behandel en die vraag waar dié kerk gevind word, dan grens hy sy denke gewoonlik na twee kante af: teén Rome en téén die Dopers. Hy vind aansluiting by Luther en kan daarom die volgende opmerking van Luther (WA 43:597) maklik beaam:

Die kerk van God is oral daar waar die Woord van God gepreek word, of dit nou in die middel van die Turke se land, of die pous se gebied of die hel self is. Want dit is die Woord van God wat die kerk bou, wat heer is oor alle ander plekke. Waar dié Woord gehoor word, waar die doop, die sakrament van die altaar en die vergewing van die sonde bedien word, staan dáár vas en maak die sekere gevolgtrekking dat dáár die huis van God is en die ingang van die hemel.

Net soos Luther praat Calvyn ook van die duidelike merktekens van die ware kerk (Inst 4.1.9) en stel dat die kerk van die geloof, die onsigbare kerk (Inst 4.1.7) en die sigbare één is, want Jesus Christus is die hoof van die kerk wat sy liggaam is en Hom dien. 
Daarom word die sigbare kerk gemeet aan die maatstaf van die onsigbare. Calvyn gee egter toe dat die mens, in die georganiseerde kerk, nie die moontlikheid het om tussen die ware gelowiges en die geveinsdes te onderskei nie. Hy beklemtoon egter dat nié die kwaliteit van die lidmate die kerk konstitueer nie, maar die kwaliteit van die prediking van die Woord en die bediening van die sakramente, die genademiddels wat Christus aan sy kerk gegee het. Daarvolgens kan die kerk beoordeel word.

Calvyn beklemtoon dat die dissipline in die kerk bewaar moet word om juis so die suiwerheid van die prediking te verseker en die gelowiges se strewe na die dankbare gehoorsaamheid aan God en die heiliging te rig. 'n Verdere belangrike rede vir die handhawing van die dissipline is die feit dat die gelowiges, deur die geloof, met Christus verenig is. Indien die gelowiges hulle in leer of lewe sou misgaan, dan reflekteer dit op die eer van Christus en dan kom vanselfsprekend die dissipline na vore. Tog beskou Calvyn, anders as Bucer, die dissipline nie as 'n merkteken van die ware kerk nie (Inst 4.12.5). Calvyn sien dit as taak en strewe van die kerk om met sy bestaan in die wêreld, dit sigbaar te laat word wat aandui dat die kerk inderdaad die liggaam van Christus is wat heilig genoem word. Dat Calvyn die kerk heilig noem, beteken nog nie dat die kerk heilig is nie. Hy betoog:

Daaruit volg dat die kerk se heiligheid nog nie volmaak is nie. Die kerk is derhalwe so heilig dat dit elke dag daarin vordering maak, maar nog nie volmaak is nie. Dit gaan elke dag vooruit maar het nog nie die eindpunt van heiligheid bereik nie ....

Dit is die rede waarom Calvyn (Inst 4.1.8) vra dat as daar na die kerk, dit wil sê die gelowiges, gekyk word "'n sekere liefdesoordeel' gebruik moet word.

Vir Calvyn is die feit dat die kerk direk met Christus verbonde is, dat Christus die hoof van sy liggaam is waaraan Hy die genadegawes van die Heilige Gees verleen, 'n uitgangspunt in sy denke oor die kerk. Dit is opvaliend dat die beeld van die kerk as die liggaam van Christus wat aan Paulus ontleen is (Rom 12:5; 1 Kor 6:15; 12:12, 27; Ef $1: 22 ; 4: 12,16 ; 5: 30 ;$ Kol 1:24; 3:15) en van die hoof en die liggaam (Kol 1:18), die beeld is wat Calvyn die meeste gebruik en waarmee hy die kerk, die gemeenskap van die gelowiges, beskrywe. Daarmee word duidelik dat Jesus Christus die handelende subjek in die kerk is (Heidelbergse Kategismus, Vraag en Antwoord 54). Aangesien dit die belydenisskrif is wat die meeste in die Calvinistiese kerkhervorming gebruik is, gee dit 'n consensus opinio weer.

Die kerkbegrip van Calvyn is al dikwels uiteengesit. By Calvyn self word dit in sy Institusie (veral in Boek 4), in die belydenisskrifte wat hy opgestel het, kerkordes en ander geskrifte gevind. In sy uiteensettings oor die kerk staan Calvyn in die midde van die reformatoriese tradisie en word daar ' $n$ merkwaardige eenstemmigheid gevind met 
die ander reformatoriese vadere. Wat die kerkorde betref, en in sake soos die verhouding van die kerk en die owerheid, die kerk en die wêreld, is daar egter opvallende verskille met die Lutherse standpunt. Oor die essensie, wat Avis (1981:36) die Christologiese sentrum van die kerkbegrip noem, is daar egter nie verskille nie.

Om Calvyn se uitsprake oor die kerk reg te verstaan, is dit nodig om die konteks waarin hy dit gesê het, óók in berekening te bring. Hoewel Calvyn se geskrifte nie veel blyke daarvan gee nie en in 'n rustige betoogtrant geskrywe is, is dit tog so dat Calvyn in ' $n$ besondere stroomversnelling van die tyd geleef het. Calvyn werk in die tyd van die vervolging en word, volgens Oberman (1988:33), die hervormer van die derde periode. Hy stel dit so:

Calvijn daarentegen spelt de Schrift in het licht van de vervolging der Kerk en richt zijn brieven, commentaren en preken aan de gemeentenonder-het-Kruis, die met ogen verduisterd door bloed en tranen niets zien van Gods almacht en trouw en tegen alle tekenen in vasthouden aan het ene Woord: Hij kent de zijnen, Hij laat niet varen de werken die zijn hand begon ... Want, zoals Calvijn terecht waarschuwde, tot de ware Kerk behoren kruis en vervolging, ook wanneer er soms oases zonder vervolgingen zijn ....

(Oberman 1988:48-49)

Ten slotte: Dit is vanselfsprekend dat hier nie 'n volledige ekklesiologie van die reformatore of van Calvyn gebied kan word nie. Daarom word volstaan deur enkele hooflyne te trek waarvolgens die omtrek en inhoud van Calvyn se kerkbegrip raakgesien kan word.

\section{JESUS CHRISTUS, DIE HOOF VAN SY KERK}

Die klem wat Calvyn, soos die ander reformatore, op die uitgangspunt plaas dat Jesus Christus die hoof van sy kerk is, beteken dat die kerk, die gemeenskap van die gelowiges, nie 'n skepping of ' $n$ maaksel van die mens is nie (Inst 4.1.1). Die kerk beteken vir Calvyn meestal die plaaslike gemeente, versamel rondom Woord en sakrament en nie dadelik die lands- of die algemene kerk nie. Die kerk is die liggaam van Christus wat die Koning en die Priester van sy kerk is (Inst 2.15.1-6). Daarmee dui Calvyn aan dat die kerk direk betrokke is by die persoon en werk van Jesus Christus, maar dan steeds as afhanklikes wat die hoofskap van die hoof, die sorg van die bruidegom, die trou van die herder nie kan ontbeer nie. In 1544, in sy debat met die Paryse fakulteit, beklemtoon Calvyn die hoofskap van Christus van sy kerk en beroep hom ook op Cyprianus se De unitate ecclesiae waar Cyprianus stel 'Episcopatus unus 
est ...', en dat daar dáárom net een hoof en heer van die kerk kan wees (CO 4:322). Vir Calvyn is dit van wesenlike belang dat niks die eenheid van die kerk met Christus, sy hoof, moet versteur nie (Comm in Eph 4:4-5 CO 7:38). En, voeg hy daarby: 'As ek Christus sê, dan sluit ek daarby in die doctrina (die leer of die evangelie) wat Hy met sy bloed beseël het'.

Hierdie uitgangspunt bepaal Calvyn se kerkbegrip (Bronkhorst sa:43-58), ook die van die ander reformatore en dit vorm die uitgangspunt van die kerkordenende werk van die Calvinistiese kerke gedurende die sestiende eeu (Jacobs 1959:103-104).

Dat Christus die hoof van sy liggaam is, beteken vir Calvyn dat die kerk aan die waarheid verbind is en dat die vraag na die ware kerk so beantwoord word. Die kerk is gevolglik 'n geloofsruimte waar dit om die evangelie van die regverdiging van die sondaar om Christus ontwil, die genade van God en die geloof in die drie-enige God gaan. Daarom kan die kerk nie 'n menslike skepping wees nie maar '... dit was daar van die begin van die wêreld af en sal tot die einde daar wees want Christus is 'n ewige koning, wat nooit sonder onderdane kan wees nie' (NGB, art 27).

Langs hierdie beskrywing van die kerk as die liggaam van Christus, gebruik Calvyn veral in die Institusie ook die beeld van die kerk as 'n moeder. Daarin volg hy nie net Cyprianus en Augustinus nie maar ook vir Luther wanneer hy aandui dat die kerk die versorger van die gelowiges is en dat daar buite die kerk geen heil is nie (vgl Wendel 1978:294). In hierdie verband sê Calvyn (Inst 4.1.4):

Omdat ek my egter voorgeneem het om nou oor die sigbare kerk te praat, moet ons net uit die enkele woord moeder leer hoe nodig, ja hoe noodsaaklik dit is dat ons haar moet leer ken. Daar is trouens geen ander toetrede tot die lewe tensy die kerk ons in haar skoot ontvang, aan ons geboorte skenk, ons aan haar borste voed, en ons onder haar beskerming en leiding bewaak totdat ons ons sterflike vlees afgelê. het en soos die engele is nie. En ons swakheid laat immers ook nie toe dat ons van haar skool af weggaan voordat ons ons hele lewe haar leerlinge was nie. Hierby is daar buite haar skoot geen hoop op sondevergiffenis en geen hoop op saligheid nie ....

Waar Calvyn die beeld van die moeder gebruik om die versorging van die kerk te beklemtoon, gebruik hy die beeld van die liggaam veral om aan te dui hoe Christus die heil aan die gelowiges laat toekom en hoe hulle dan bygestaan en gelei word in hulle lewe as kinders van God wat heilig moet lewe omdat God heilig is. Hier beklemtoon Calvyn dat Christus die gelowiges nie alleen direk deur sy Woord en Gees lei, voed en versorg nie, maar ook indirek deur gebruik te maak van die diens van mense. So gee 
Calvyn 'n ander inhoud aan die amp as Rome, want die ampte word nou getipeer as diensknegte van Christus en van die gelowiges en nie meer as 'n orgaan van die kerk nie (Inst 4.3.2). Die amp dien, volgens Calvyn, die evangelie maar ook die opbou in die geloof van die gelowiges wat op die fondament van die profete en apostels staan. Met hierdie standpunt skep Calvyn 'n amptelike kerk, want deur die dienswerk van die geroepe diensknegte word die evangelie verkondig, die boodskap van God se genade in Jesus Christus uitgedra. Dié amptelike kerk is gerig op die volk in wie se midde die kerk bestaan, want die Woord wil wêreldomvattend wees (Matt 28:19), en die koninkryk van God dien. Die kerk, die gelowiges, kan dus nie na binne gerig lewe nie want dit gaan om méér as die onderhouding van die liturgie en die viering van die mis. Daarom begin al die Calvinistiese kerkordes, na die verskyning van die Ordonnances Ecclésiastiques van 1541, met die amp en nié meer met die liturgie nie. Die lewensorde van die kerk is nie gerig op die liturgia sacra nie maar op die dankbare geloofsgehoorsaamheid in die wêreld. Immers, dié Christus wat die kerk verkondig en bely, is nie net hoof van die kerk nie maar ook die heer van die wêreld.

\section{DIE AMP IN DIE KERK}

Wanneer Calvyn se siening van die kerk nagegaan word en dan daarmee saam gelet word op die organisatoriese struktuur van die geloofsgemeenskap, dan val dit op hoe sober Calvyn dit alles sien. Teenoor die Rooms-Katolieke Kerk met sy massiewe ontologiese struktuur en sy pretensie om die voortsetting van die vleeswording van Christus te wees met sy vicarius Dei as hoof, omskryf Calvyn die kerk as 'die uiterlike hulp- en ondersteuningsmiddel waardeur God ons tot die gemeenskap met Christus uitnooi en ons daarin hou' (Inst 4.1.1). Hier is die kerk 'n middel en nie 'n doel nie, dit is ook nie die koninkryk van God nie, maar 'n ondersteuningsmiddel wat God gee. In die lig kan sy opmerking begryp word waar hy sê (Inst 4.3.1):

Omdat Hy egter nie met 'n sigbare teenwoordigheid onder ons woon om sy wil mondeling en persoonlik vir ons te verklaar nie, het ons gesê dat Hy die diens van mense gebruik en die diens is 'n plaasvervangende werk. Daardeur word sy reg en eer nie op die mense oorgedra nie maar slegs om deur hulle as mondstuk (self) sy werk te doen. Dit is soos wanneer 'n vakman 'n stuk gereedskap gebruik om sy werk te doen.

Dié plaasvervangende werk waarna Calvyn verwys, is die dienswerk van die ampte wat in die kerk bestaan. Hulle word deur God gekies as die beste manier waarop Hy die gelowiges kan roep, kan versorg en lei. Daarom is die kerk 'n goddelike instelling, want die gemeenskap van gelowiges is deur God met die geloof begenadig en die ampte met hulle diens is maar ' $n$ middel in die hand van God wat hulle gebruik om sy werk te doen. 
Calvyn ken drie, soms vier dienste of ampte: die biskop wat nou 'n predikant word, die doctor of leraar, die presbiter-priester wat nou 'n ouderling word en die diaken. Oor die apostels, profete en evangeliste van Efesiërs 4, sê Calvyn (Inst 4.3.4), byna kortaf dat die Here hulle '.. in die begin van sy koninkryk opgewek het ..." en hulle soms nog gebruik" ... namate die tydsgewrig dit vereis'. Dit is dus duidelik dat Calvyn nie die vroeë kerk wil herbou nie, maar die kerk wil hervorm sodat dit weer God se volk of die liggaam van Christus kan wees. Daarom maak hy 'n duidelike keuse ten opsigte van die tydelike en die blywende ampte en laat hom daardeur ook lei deur die geskiedenis van die kerk.

Twee sake is hier opvallend. Die eerste is dat nóg Luther nóg Calvyn die ampdienswerk van die kerk op die priesterskap van die gelowiges bou nie. Daar is nie 'n organiese, hiërargiese opbou van die amp as ' $n$ funksie van die kerk nie. Die dienswerk is ' $n$ instelling van God en die geroepe dienaar, wat uit die kring van die gelowiges kom, moet in die geloof en trou aan die Woord, sy opdrag uitvoer. Die priesterskap van die gelowiges, hulle mondigheid, word erken. Die dienswerk is nie daar om die gelowiges aan die amp te onderwerp nie, maar '... om die gelowiges toe te rus vir hulle diens en die opbou van die liggaam van Christus' (Ef 4:12).

Die tweede is die afwysing van die charismata as afsonderlike, blywende dienste. Calvyn oordeel dat dié dienste insidenteel is en nie berus op 'n spesifieke roeping en missio nie. Dit is moontlik dat die afgrensing teen die Dopers hier 'n rol kon gespeel het.

Die konstituerende van die dienswerk, as dit so aangedui kan word, is by Calvyn enersyds die diensbaarheid aan die Woord en andersyds die verantwoordelikheid teenoor die Heer van die kerk vir die gelowiges wat aan die sorg van die dienskneg toevertrou is. Dit skep in ons dae verleentheid en weerstand, want die dienskneg met sy plaasvervangende werk, wat as ' $t$ ware die Heer van die kerk teenoor die gelowiges verteenwoordig, is nie meer aanvaarbaar nie aangesien die mens die uitgangspunt, ook in die teologie, geword het (Burden 1994:114). By Calvyn is die ampte egter uitdrukking van God se sorg vir die gelowiges om hulle voor te gaan en die eer van God in die wêreld te verseker.

Die vier ampte soos Calvyn dit aangedui het, het in die Calvinistiese kerklike tradisie voortgeleef. Met die loop van die tyd het die inhoude enigermate verskuif en daarom kan dit goed wees om net weer kortliks op Calvyn se vormgewing van die ampte te let.

\subsection{Die predikant}

Dit is opvallend dat die predikant deur Calvyn eerder aangedui word as die 'opvolger' van die apostels, as van die vroeg-kerklike biskop (Inst 4.3.6) want sy taak is om te preek, te doop en die Nagmaal te vier. 'n Opvallende verskil met die Rooms-Katolieke 
Kerk se ampsopvatting is dat die predikant nie ' $\mathrm{n}$ character indelibilis met die inseëning in die amp ontvang nie, maar dat die amp funksioneel gesien moet word en dat die predikant in 'n vaste standplaas sy dienswerk moet verrig (Inst 4.3.7). Die dienswerk is deur God ingestel en dit word effektief gemaak deur die werk van die Heilige Gees. Die predikant is altyd 'n geroepe gelowige wat deur studie en opleiding die bekwaamheid verwerf het om die Skrif uit te lê. Om 'n predikant te kan word, is toelating tot die amp en 'n beroep na 'n standplaas deur 'n vergadering van die ampte, 'n voorwaarde (Inst 4.2.10). Sonder sodanige beroep is die dienswerk nie moontlik nie. Daarvoor was daar twee redes. In die eerste plek verwys Calvyn na 1 Korintiës 14:40 dat alles 'gepas en ordelik' moet geskied en ten tweede wil hy die Rooms-Katolieke praktyk vermy van priesters wat as sodanig gewy is, maar omtrent nooit 'n mis gevier het nie. Vir Calvyn is die dienswerk altyd funksioneel (Comm in Jer 29:30-32, CO 38:611).

Die beroepe predikant moet vir sy diens in die gemeente bevestig word en daarvoor word die voorbeeld van die vroeë kerk aangevoer. 'Hoewel daar geen bepaalde beginsel oor die handoplegging bestaan nie, sien ons nogtans dat die apostels dit voortdurend toegepas het en daarom behoort die versigtige handhawing daarvan vir ons as beginsel te dien' (Inst 4.3.16). Op 'n ander plek sê Calvyn dat die bevestiging nie 'n wêreldlike handeling is nie, '... maar 'n wettige inseëning voor God wat nie anders voltrek word nie as deur die krag van die Heilige Gees' (Comm in 2 Tim 1:6, CO 52: 349-350). Dié inseëning wys heen na die gawes van die Gees wat nodig is om die geroepe dienaar bekwaam te maak om sy dienswerk te kan doen. Die essensie van hierdie dienswerk is altyd die verkondiging van die evangelie van Jesus Christus, die gekruisigde en opgestane Heer.

Volgens die Geneefse kerkorde, Artikel 16 (vgl Pont 1981:25), word van die predikant verwag om by die toetrede tot die amp ook die ampseed af te lê wat soos volg gelui het:

Ek beloof en sweer dat ek in die diens waarvoor ek beroep is, God getrou wil dien in so ver dat ek sy Woord tot opbouing van hierdie kerk, waaraan ek my verbind het, suiwer sal verkondig en dat ek sy leer nie sal misbruik nie om my vleeslike behoeftes te dien nie of om ' $n$ lewende mens welgevallig te wees nie, maar dat ek die Woord na my beste wete en volgens my gewete sal uiteensit om so die verheerliking van God en die voordeel van sy volk te dien, wie se skuldenaar ek is.

Die ampsopdrag word in die kerkorde nie breed uitgespel nie, maar dit sentreer, volgens die Geneefse praktyk, rondom prediking, sakramentsbediening, gebede en die pastorale versorging van die gemeente. 


\subsection{Die doctor of leraar}

Langs die predikant plaas Calvyn die doctor of leraar wat 'n aparte amp langs dié van die herder is (Inst 4.4.1). Sy taak is in hoofsaak om die Skrif uit te lê (Inst 4.3.5). In die Geneefse kerkorde (Pont 1981:28-29) word die leraar as tweede amp genoem. Daar het hy die taak om die gelowiges te onderrig ' $\ldots$ in die heilige leer sodat die suiwerheid van die evangelie nie geskaad word nie' (Art 44). Met ander woorde, hulle vorm ' $n$ bolwerk teén die kettery. Terselfdertyd is dit hulle diens om predikante op te lei. So word die doctor gesien as die leraar, die onderwyser in en van die kerk.

Die diens het aanvanklik goed gefunksioneer, veral as gelet word op die geskiedenis van die Geneefse Akademie (Parker 1975:126-128). Dit was egter nie oral moontlik om die teologiese opleiding as 'n kerklike opleiding te struktureer waar die reformasie deurgewerk het nie. So het dit gebeur dat hierdie dienswerk geleidelik na die rand van die kerklike lewe beweeg het. In Nederland word die universiteite, beginnende met die een te Leiden in 1575, owerheidsinstellings waar die kerk geen inspraak het nie. Dit maak die opleiding van predikante los van die kerk, want die professore het met hulle aanstelling aan die universiteit uit die diens van die kerk getree en slegs emeritaatsregte behou. In die humanistiese atmosfeer van die universitêre wetenskapsbeoefening, het baie professore nie daarin geslaag om die verbondenheid met die kerk en sy leer te handhaaf nie. Algaande het dit probleme vir die Nederlandse kerk geskep. Die teologiese professore het nie meer gefunksioneer as die bolwerk teen kettery nie, maar was juis diegene wat die kettery in die geloofsgemeenskap ingedra het. Arminius word in hierdie verband 'n voorbeeld wat heelwat navolging gevind het terwyl die kerk self, deurentyds, magteloos was om daarin 'n verandering te bring. Noordmans het ' $n$ keer die spanning tussen die kerk en 'n gesekulariseerde teologiese fakulteit so getipeer:

Of een boer verstand heeft van theologie, kan misschien een enkele maal in twijfel getrokken worden .... Maar over een preek kan hy zeker oordelen, anders deugt deze niet. Hij weet best wat zonde is en dat weet een professor niet; want het is waar wat Kierkegaard zegt, dat de zonde in de preek thuishoort en niet in de wetenschap.

(Noordmans 1984:487)

Die spanning tussen kerk en teologiese opleiding kan verdwyn waar die opleiding 'n kerklike opleiding is, waar ook die professore hulle hou aan die belofte dat hulle die kerklike leer of belydenis '... van harte onderskryf en getrou sal verkondig' (Nederduitsch Hervormde Kerk van Afrika, Kerkwet en Bepalings, Bepaling 73). Juis by die kerklike teologiese opleiding lê die klem, vanselfsprekend, op die Skrifverklaring en die onderrig in die suiwere leer in 'ooreenstemming met die geloof wat ons bely' (Rom 12:6). 
In die eerste uitgawe van sy Institusie van 1536 (Simpson 1980:6) sê Calvyn: 'Die Vader het dus sy Seun nie sonder rede met 'n buitengewone prerogatief as leraar oor ons aangestel toe Hy Hom na ons gestuur het en ons gebied het om na Hom en na geen ander mens te luister nie'. Die kerk, die geloofsgemeenskap wat aan Christus verbind is, leef en dink vanuit ' $n$ ander kennisbron as die wetenskap en eis vanselfsprekend ' $n$ primaat op vir die evangelie van Jesus Christus waarvan die kerk 'n dienskneg is (vgl 1 Kor 1:18-31).

\subsection{Die ouderling}

Die volgende amp wat Calvyn na vore bring is die regerende oudste, die ouderling. Dit was Ignatius wat in die vroeë kerk in sy Ad Magnesios die 'biskop' tipeer het as die man van genade en die 'oudste' as die man van die wet. Calvyn het, na sy verblyf in Straatsburg waar die Lutherse predikante sonder ondersteunende dienste of ampte gewerk het, die diens van die ouderling op grond van Skrifgegewens en die praktyk van die vroeë kerk, uitgebou. Daarby het Bucer se beklemtoning van hierdie amp ook 'n rol gespeel (Van 't Spijker 1971:399). Calvyn noem die ouderlinge 'ouer mense wat uit die gewone mense gekies is' (Inst 4.3.8) om in 'n vergadering saam met die predikante, die gemeente te regeer. Dit wil sê: om op grond van die evangelie die dissipline te handhaaf. In die Geneefse kerkorde, Artikel 48, word die censura morum en die disciplina aan die ouderlinge opgedra (Pont 1981:29).

Noordmans beskou die dienswerk van die ouderling as van onskatbare waarde en sien in die vormgewing van hierdie amp iets van die genialiteit van Calvyn en sy vermoë om die Skrif so te verstaan en te gebruik dat die kerk daardeur gedien word. Dit is vir hom die amp wat die volkskerklikheid van die kerk die beste illustreer (Noordmans 1984:447).

Die ouderling was in die Calvinistiese kerke vooraanstaande figure uit die gemeente en dit is opvallend dat daar steeds na hulle verwys word as gelowige manne, waardig, heilig wat aangewys is om te regeer, te vermaan en tereg te wys. So het die ouderling langs die predikant gestaan as medewerker van die predikant terwyl hulle wederkerig oor mekaar die opsig hou. Dit was die taak van die ouderling om altwee tafels van die Wet te handhaaf en almal in gehoorsaamheid aan God te hou. Daarin is hulle uniek in hulle regeeropdrag.

'n Interessante aksentverskuiwing kom na vore in die Bevestigingsformulier vir Ouderlinge wat in 1586 in die Nederlandse kerk aanvaar is. Daarin word die ouderling in die besonder vermaan om die predikant te weerhou van tirannie en om toe te sien dat daar nie wolwe in die kudde inkom nie. Die potensiële wolf waarteen die ouderling moet waak, is óok die predikant! Daardeur word die ouderling nou in die besonder die opsighouer oor die predikant in plaas van medewerker, soos die Nederlandese Geloofsbelydenis, Artikel 30, sy taak omskryf. 
Die ouderling word in die Nederlandse kerk ook, na die voorbeeld van die Franse kerk waar die sinodale regeringsisteem ontwikkel is, 'n afgevaardigde na die meerdere vergaderings van die ampte.

Die ouderling, gekies uit die 'gewone mense' en wat net deeltyds vir 'n omskrewe periode tot sy dienswerk geroep word, was ook die waarborg daarvoor dat daar nie weer 'n clerus in die kerk ontwikkel het nie. Dit was veral die ouderling se taak om ag te gee op die belydenis en lewe van die gelowiges. Hy moes die huisgesinne besoek om vas te stel wat uit die saad van die Woord gegroei het en daaroor verslag te doen. Hy moes die heiligheid van die volk van God kontroleer. Noordmans het daarop gewys dat Calvyn die volk van God belangriker geag het as die instituut of organisasie van die kerk (vgl ook Berkhof 1955:186-187). Hy stel dit so:

Door de presbyterie hebben de gereformeerde gemeenten en half-politieke vorming ondergaan. Politiek in de zin van een civitas Dei, een burgerschap Gods. Nu de clerus wegviel word het volk zelf een instelling. Het moest leren leven op die hoogte, waar het door de prediking was geplaatst, boven zijn natuurlijk niveau, boven zijn spel en dans .... Zulk een mobilisatie van het christenvolk-zelf was in de kerk nooit eerder ondernomen.

(Noordmans 1984:624)

Calvyn wou in die stadstaat Genève die hele samelewing onder die tug van die gehoorsaamheid aan God alleen bring. Daarmee is die vraag aan die orde gestel: is die kerk in die eerste plek ' $n$ organiese en lewende eenheid, 'n volk gebore uit die onverganklike saad van die Woord van God (1 Pet 1:23; Matt 16:17; 1 Kor 15:50), of is dit 'n instituut, 'n organisasie, 'n vereniging vir die instandhouding van die godsdiensoefening, soos die negentiende eeu dit wil? Calvyn het daaroor geen twyfel gehad nie en daarom is die ouderling by Calvyn die regeerder van die volk van God, die handhawer van die dissipline wat binne in die volk van God staan, maar terselfdertyd die taak het om die teokrasie in die wêreld te verwerklik. Daarom is dit nie so vreemd dat die lewensorde wat Calvyn vir die volk van God skep as presbiteriaal aangedui word nie.

\subsection{Die diaken}

Calvyn is terdeë daarvan bewus dat die begrip diakonia 'n breër strekking het as net die arm- en siekeversorging. Tog dui hy die armversorgers in die kerk as diakens aan (Inst 4.3.9). Vanweë die omstandighede in Genève het Calvyn 'n voorsiening gemaak vir die versorging van siekes, ellendiges en diegene wat 'n heenkome in die hospitium gesoek het. Hulle is ook as diakens aangewys en die taak het Calvyn as geskik vir die 
vrouens geag. Hy stel (Inst 4.3.9): 'Vrouens kon trouens geen ander openbare (kerklike) amp beklee behalwe as hulle hulle gewy het aan die versorging van die armes nie'.

Die amp van die diaken het nie in die arm- en siekeversorging opgegaan nie, maar het steeds die inhoud behou dat hulle dienswerk ook moes bydra tot die opbou van die gelowiges in die geloof. In die Franse kerk het dit beteken dat die diaken nie net 'n opdrag ten opsigte van die kategese van die armes en die siekes gehad het nie, maar ook dat die diaken, wanneer die predikant afwesig was, in die godsdiensoefening moes voorgaan deur die diens van die gebede waar te neem en 'n Skrifgedeelte te lees sonder om te preek (Niesel 1938:77).

Hoewel die Franse kerkordelike tradisie, die Nederlandse Geloofsbelydenis, Artikel 30 en die sinode van Emden 1571, die diaken 'n lid van die kerkraad maak, het die Provinsiale sinode van Dordrecht 1574, op grond van die Geneefse voorbeeld en die plaaslike omstandighede, die lidmaatskap van die kerkraadsvergadering beperk tot die ouderlinge en die predikante. Slegs wanneer die diaken as 'n hulpouderling opgetree het, was hy lid van die kerkraadsvergadering. Die betrokke tradisie is ook in SuidAfrika gehandhaaf vanaf 1652 totdat die Algemene Kerkvergadering van 1853 dit gewysig het.

Die reformatore wat die uitgangspunt gehandhaaf het dat Jesus Christus die hoof van die kerk is, het onder leiding van Calvyn 'n kerklike organisatoriese struktuur ontwikkel waar die amp as dienskneg en as mondstuk van Christus werksaam was. So is 'n kerkvorm geskep wat in staat was om die storms en beproewings van hierdie wêreld te trotseer.

Deur die ministerium ecclesiae so uit te bou wil Calvyn uitdrukking gee aan een van sy sentrale stellings: die eenheid in die geloof met Christus, die direkte verbondenheid van die liggaam aan die hoof is die saak waarom dit gaan en dit kan alleen verwerklik word deur gehoorsaamheid aan die Heilige Skrif, die evangelie, die doctrina, die Woord.

\section{DIE KERK AS VOLK VAN GOD}

Naas die beeld van die kerk as die liggaam van Christus word die ander beeld van die kerk as volk van God, wat saamhang met die siening van Christus as ewige koning, ook gebruik. Dit word veral gebruik vanweë die verstaan van die genadeverbond van God, en word in Zürich deur Zwingli beklemtoon teenoor die Dopers. Die genadeverbond waarvan die doop, net soos die nagmaal, ' $n$ teken is, word gesien as die grondslag waarop die volk van God gebou word - ook omdat die inhoud van die verbond Christus is (Alting von Geusau 1963:155-166). 
Calvyn verwys altyd na die unio foederis en die twee gestaltes daarvan in die Ou Testament en Nuwe Testament en dit is die manier waarop hy die deurlopende in die twee bedelings sien (Inst 4.16.6). Net soos die besnydenis is die doop confirmatio foederis, ter versterking van die geloof van die ouers en die kinders. Die 'genadeverbond, wat op Christus gebou is, is vir Calvyn die deurlopende in God se handeling met sy volk (Comm in Jer 33:15, CO 39:64; Comm in Act 2:39, CO 48:291). Die kerk in die Nuwe Testament, die nuwe Godsvolk, is vir Calvyn die teken van die tweede redding (Comm in Dan 8:1, CO 41:87) en Christus is die herskepper van God se orde, die grond en sentrum van die verbond (Inst 3.25.3). Na die vervulling van die verbond deur Christus (Comm in Rom 15:8, CO 49:273) het die nuwe verbond nou ook ruimte vir die nie-Jode (Comm in Gen 17:7, CO 23:238-239). Die ou verbond is as't ware verbreed om nou alle volke te akkomodeer. In Institusie 4.2.11 betoog Calvyn: 'Toe Hy sy verbond in Frankryk, Italië, Duitsland, Spanje en Engeland gevestig het ... het $\mathrm{Hy}$ met die doel dat sy verbond nogtans ongeskonde daar sou bly, ten eerste die doop daar behou as 'n getuienis van sy verbond ...'. Daarmee wil Calvyn aandui hoe die volkere tot die verbond toegevoeg is (Inst 4.1.7-8; 4.2.5). Dit is, terloops, vir Calvyn natuurlik om kollektief en nie individualisties te dink nie.

Hierdie siening van die kerk as verbondsvolk het ook invloed gehad op die waardering van die samelewing wat in sy geheel 'n gedoopte samelewing was. So was kerk en burgerlike gemeenskap maar twee kante van dieselfde saak want almal moes, kragtens die Rykswette, gedoop wees. Wat dit beteken, kom skerp na vore wanneer Calvyn in 1536, as hy met sy werksaamhede in Genève begin, eis dat al die burgers van die stad met ' $n$ eed die belydenis van die kerk moet aanvaar, om so die besluit van 25 Mei 1536 'om na die eis van die evangelie te lewe' te bevestig en die grense van die kerk vas te stel (Pont 1991:106-116).

So ontstaan binne die ruimte van die reformasie, as vanselfsprekend, volkskerke wat die volk van God en die natuurlike volk binne dieselfde grens gehad het. Baker (1980:110) stel ten opsigte van die situasie in Zürich: 'Bullinger did not view the commonwealth in terms of church and state but rather as the people of God gathered together in a Christian society based on the covenant. The church did not exist within society, it was society .... It was the Christian community'. So gesien was die volkskerk in die sestiende eeu net so normaal en vanselfsprekend in die Christelike gemeenskap as die teologiese opleiding van predikante en dit terwyl nie een van die twee só in die Skrif vermeld staan nie.

Die volkskerklikheid van die kerk het 'n eie beeld getoon in die sestiende eeu, want dit bring mee dat die vlugtelinggemeentes steeds organisatories aparte gemeentes in die gasheerstad of land was. Dit gebeur met Datheen en die Nederlandse gemeente 
in die Paltz, met Knox en die Engelssprekende gemeente in Genève, met Calvyn en die Franssprekende gemeente in Straatsburg. Dit terwyl daar in geloof, leer en teologie en selfs die inrigting van die godsdiensoefening geen wesenlike verskil met die omringende gemeentes was nie.

Dit toon hoe reeds in die sestiende eeu taal, kultuur, lewenstyl vanselfsprekende faktore was wat die lewe van die Godsvolk in die wêreld gekleur het. Vandaar dat die reformatoriese vadere die Bybel in die volkstaal vertaal het en die godsdiensoefening en die belydenisskrifte van die kerk in die volkstaal gehou het. Daarmee is in beginsel die eenheidskultuur van die Latynse, Roomse-Katolieke kerk verwerp, saam met sy leer en struktuur.

\subsection{Die eenheid van die verbondsvolk}

Dit kan miskien as 'n aksioma gestel word dat die reformatoriese vadere geen erg in organisatoriese, strukturele eenheid van die kerk gehad het nie. Dit hang saam met die feit dat ook die georganiseerde kerk as 'n geloofsgemeenskap, as volk van God verstaan is. Daarom het die merktekens van die kerk ook dáárop betrekking (Inst 4.1.812) en nie op die struktuur van die kerk nie. Calvyn het dit so gestel: 'Daarom, as ons wil saamstaan om die eenheid van die kerk te bewaar, laat dit geskied deur 'n gesamentlike aanvaarding alleen ten opsigte van die Waarheid van Christus' (Interim adultero-germanum 1549, CO 7:605).

Vir die reformatore is die volk van God 'n geloofsgemeenskap en die eenheid van die gelowiges met Christus is die saak waarom dit gaan. As dit bestaan, is daar eenheid onder die gelowiges (Supplex exhortatio ad caesarem 1544, CO 6:509) en daardie eenheid met Christus is geleë in die evangelie wat Hy met sy bloed beseël het.

In die Kategismus van Genève 1545 (Simpson 1981:20) word die eenheid en die katolisiteit van die kerk in een asem hanteer. 'Daardeur word ons geleer dat net soos al die gelowiges één Hoof het, almal in een liggaam saam behoort te groei sodat daar net een kerk, wat oor die hele wêreld versprei is, en nie baie kerke nie, tot stand kan kom'. By Calvyn het die gedagte aan ' $\mathrm{n}$ institutêre, organisatoriese eenheid nié bestaan nie, omdat vir Calvyn die pura et sana doctrina die wesenlike kenmerk van die kerk en die fondament van die eenheid is. Eenheid en algemeenheid lê in die consensus in puram doctrinam (Nijenhuis 1959:301-303) en as dit nie bestaan nie, is daar nie van eenheid sprake nie, want dan is daar geen eenheid met die hoof van die kerk, Christus, nie.

Vir die reformatore lê die heilsbetekenis van die kerk nie in die kerk self nie, nie in wat die kerk is nie maar in die funksie van die kerk, in die diensgestalte van die kerk, in die feit dat die kerk 'n instrument in die hande van God, die Heilige Gees, is. Daarom is die kerk by Calvyn die ingang tot die lewe, maar dan is die kerk alleen 
belangrik vanweë sy diensfunksie, terwyl die kerk as organisatoriese struktuur in homself nié belangrik is nie (Inst 4.1.3, kyk ook Graafland 1989:41-43). Die aandrang op sigbaar-organisatoriese eenheid is 'n negentiende-twintigste-eeuse verskynsel waar die geloof in Christus dikwels as ' $n$ menslike daad verstaan word en nie meer as 'n genadegawe van God nie. Daarom word in hierdie dae geoordeel dat die eenheid van die kerk deur mense verwerklik kan word, as een kerklike struktuur opgerig word.

\section{DIE KERK AS EIESOORTIGE GELOOFSGEMEENSKAP}

Die eiesoortigheid van die geloofsgemeenskap word in die sestiende eeu nie so skerp beklemtoon soos in die latere geskiedenis van die kerk nie. In die sestiende eeu gaan dit om afgrensing teen Rooms-Katolieke Kerk en die Dopers en nog nie soseer teen die heidendom nie. In die stellingname teenoor die Dopers is die reformatore bewus van die antitese tussen kerk en wêreld, maar hanteer dit anders as die Dopers.

By Calvyn word die antitese bepaal deur die feit dat die Woord en die Heilige Gees 'n geheiligde gemeenskap van gelowiges vorm. Hierdie kerk word die stimulans vir die vernuwing van die hele gemeenskap, want leer en lewe moet in ooreenstemming wees. Die vernuwing sal tot stand kom deur die verkondiging van die koningskap van die opgestane, verhoogde Christus. Oor die koningskap van Christus sê Calvyn (Comm in Fil 2:10, CO 52:29):

Dit is egter met die koninkryk van Christus so gesteld dat dit daagliks groei en ten goede vorder. Dit is egter nie volmaak nie en sal dit ook nie wees voor die dag van die laaste oordeel nie. Altwee stellings is waar, naamlik dat nou reeds alles aan Christus onderwerp is én dat hierdie onderworpenheid nie volledig sal wees voor die dag van die opstanding nie. Want eers dan sal volmaak word wat nou nog maar begin is.

Die feit dat Christus koning is, het gevolge in dié sin dat die wet van God, die dankbare gehoorsaamheid, nou reeds nagestreef word en daardeur word die wêreld rondom die kerk vanuit die kerk, beïnvloed. Deur die prediking van die evangelie word die lewe van die gemeenskap ook onder die dissipline, die tug van Christus, gebring.

Calvyn vra dus, anders as die Doperse wêreldontvlugting en die Rooms-Katolieke se asketiese, monnikevroomheid, nié dat die gelowiges hulle uit die wêreld sal terugtrek asof die wêreld die essensieel-sondige is nie, maar die heiliging van die wêreld, want Calvyn (Comm in 2 Kor 6:15, CO 50:81)stel: 'Dit is die spesiale prerogatief van God dat Hy elke plek wat Hy vereer met sy teenwoordigheid, ook heilig'. Calvyn eis van die gelowiges die sanctitas et puritas vitae in die wêreld, nie die ontvlugting uit die wêreld nie. Hy stel dit so (Comm in 2 Cor 6:17, CO 50:83): 
Want terwyl ons nog in die wêreld is, is ons tog met God versoen en gered uit die onreinhede van die wêreld. Daarom moet ons nie uit hierdie lewe uittrek om vry te wees van die onreinhede nie, maar ons moet eerder die deelname daaraan vermy en verwerp. Kortom, wanneer ons met 'n ware geloof steun op die weldaad van die versoening, moet ons versigtig wees om ons nie te verontreinig deur kontak met vuil dinge nie.

Hier word dus 'n gemeenskap van gelowiges geteken wat vanuit die geloof in die wêreld moet inbeweeg, om daar die teokrasie uit te leef. Dit is, terloops, die teenoorgestelde van die eis wat vandag aan die kerk gestel word, naamlik dat die kerk moet voldoen aan die basiese eise van die ideologieë van die wêreld om in die wêreld aanvaarbaar te wees.

\subsection{DIE SUIWERE LEER}

Die kerk is die ruimte waar die mens, deur die prediking van die evangelie, die geloof ontvang en waar die geloof gevoed en gesterk word (Inst 4.1.5). Op die genadegawe van die geloof, antwoord die gelowiges deur hulle geloof te bely en uit te leef. So is die kerk verbind met die profete en die apostels en die Christusbelydenis van die kerk van alle tye en plekke. Daarin lê ook die algemeenheid van die kerk want die doctrina en die geloof daarin is '... die heilige band van die broederlike eenheid ...' (Comm in Act 15:1-2, CO 48:336).

Daarom beklemtoon Calvyn die suiwerheid van die leer en die belydenis maar nié die kwaliteit van die gelowiges nie, omdảt die kerk op aarde altyd 'n corpus permixtum is (Comm in 1 Joh 2:19, CO 55:323). Vir dié rede is die tug belangrik om almal in gehoorsaamheid te hou. Maar belangriker as dit is die vraag na die doctrina, die prediking van die Woord waardeur die kerk bestaan (Comm in Eph 2:20, CO 51:175, ook Comm in 1 Tim 5:17, CO 52:315). Die kerk is immers die getroue bewaarder van God se waarheid en dié waarheid word aan die kerk toevertrou met die opdrag om die verkondiging van die Woord suiwer te hou. Dié suiwerheid verwys daarna dat die Woord na die reël van die geloof van die kerk van alle eeue verkondig sal word (Inst 4.1.10). Dit is in hierdie verband wat Calvyn na die capita doctrinae, die summa religionis verwys wat onveranderlik is (Inst 4.1.12).

Die hoofpunte van die ware leer, soos Calvyn dit aandui, beklemtoon die trinitariese karakter van die heil. Veral in die Institusie word dit duidelik dat nie net die objektiewe nie, maar ook die deurleefde heil, as sentrum van die leer beskou is. Terselfdertyd ken Calvyn ook minder belangrike elemente van die leer waaroor daar verskil kan word sonder dat die geloofseenheid versteur word (Inst 4.1.12). Calvyn dui as die noodsaaklike kern van die leer die volgende aan: die leer oor God, oor Jesus 
Christus, met die klem op die verlossing, die leer oor die genade, dit wil sê oor die regverdiging deur die geloof alleen en die leer van die uitverkiesing. Dit is die essensie van die pura doctrina, die Christologiese middelpunt van die leer en die geloof van die kerk. Dáár loop die grens tussen Waarheid en nie-meer-waarheid-nie. Die pura doctrina waarna Calvyn altyd verwys, is hierdie summa religionis, want as dit nie verkondig word nie, dan is daar, soos Luther sou sê, slegs sprake van ydele geklets.

$\mathrm{Na}$ Calvyn verander die siening ten opsigte van die noodsaaklike leerstukke wat altyd en oral gehandhaaf moet word en waarin geen afwyking toegelaat word nie. Dan kom die vraag na vore, naamlik met watter leerstukke die belydenis van die sola gratia verbind moet en kan word. Soos die omstandighede dan verander, verander die beklemtoning ten opsigte van die summa religionis.

In hierdie verband kan daarop gelet word dat Calvyn nogal klem daarop gelê het dat die reg om die leer te omskrywe of te bepaal nie, in die hande van mense lê nie. 'Ons moet in gedagte hou', sê Calvyn, 'dat al die gesag en aansien wat die Gees in die Skrif aan of die priesters of die profete of die apostels of aan die opvolgers van die apostels verleen, nie aan die mense self verleen word nie maar ten volle aan die amp waarin hulle aangestel is, of om dit korter te stel, aan die Woord waarvan die bediening aan hulle opgedra is' (Inst 4.8.2).

\subsection{Die belydenisskrifte}

Die pura doctrina van die kerk staan volgens Calvyn absoluut onder die gesag van die Skrif (Inst 4.8.8), en die Skrif alleen is onfeilbaar as dit oor die doctrina gaan (Inst 4.8.13). Tog het die Calvinistiese kerke in die sestiende en sewentiende eeu 'n hele reeks belydenisskrifte geproduseer. Daarmee word duidelik dat die volk van God as 'n belydende geloofsgemeenskap verstaan is waar die belydenis nie net aan die kerk voorafgaan nie, maar ook die kerkwees van die kerk bepaal het. Dit was ook vanselfsprekend dat 'n verskil in belydenis gedui het op 'n verskil in kerkorde en die lewensorde van die kerk.

Die belydenisskrifte in die sestiende eeu is nie almal van dieselfde soort en het nie almal dieselfde bedoeling nie. Waar die kerkhervorming as ' $n$ beweging begin het om die evangelie van Jesus Christus weer duidelik na vore te bring, het die vraag spoedig ontstaan wat die evangelie presies sê oor God, die geloof in God en die lewe van die gelowige. Hier lê die eerste oorsaak vir die ontstaan van 'n geloofsbelydenis. Dit is opgestel met die oog op die gebruik in eie kring as 'n riglyn by die lees van die Bybel en as 'n onderwysende, opvoedende uitspraak sodat daar eenheid in geloof en optrede sal wees. Daarvoor, het Calvyn geoordeel, kan 'n kategismus die beste gebruik word. In 'n skrywe aan Edward Seymour, die hertog van Somerset op 22 Oktober 1548 (Schwarz 1962:443), gee Calvyn uitvoerig raad oor die manier waarop die kerk hervorm kan word. Dan sê hy: '... dat daar 'n samevatting van die leer sal wees wat 
almal moet verkondig'. Alle prelate en predikante moet met 'n eed beloof dat hulle hierdie belydenis sal onderhou en niemand moet in 'n kerklike amp bevestig word wat nie beloof het om aan hierdie ooreenkoms vas te hou nie.

Verder is 'n gemeenskaplike samevatting van die leer vir die kinders en die ongeleerdes nodig sodat hulle deur hierdie middel vertroud kan raak met die goeie leer, sodat hulle die leuens en afwykings wat daarteen ingebring kan word, goed kan onderskei.

Glo my, ... die kerk van God kan nie sonder 'n goeie kategismus voortbestaan nie .... Hierdie Kategismus kan vir 'n dubbele doel gebruik word, naamlik om die gemeente te onderrig sodat hulle die prediking kan benut en dat hulle ook kan onderskei wanneer een of ander geleerde man 'n vreemde leer sou voordra .... Verder dink ek ook dat dit goed, selfs noodwendig is om die predikante te verplig om 'n bepaalde skriftelike vorm van die leer te aanvaar sowel om die onwetendheid en eenvoud van sommige te hulp te kom asook om die eenstemmigheid en eenheid van alle gemeentes beter tot uitdrukking te bring. In die derde plek (is 'n kategismus) nodig om alle nuuskierigheid en die nuwighede wat mense uitdink wat alleen maar iets besonders wil hê, onmoontlik te maak. Soos reeds gesê moet die Kategismus sulke mense beteuel.

Hier gaan dit dus om die funksie van die geloofsbelydenis in die eie kring. Indien die geloofsbelydenis buite die eie kerk gebruik wil word, sien Calvyn dit as 'n dokument wat die eenheid van leer en geloof met die susterkerke uitdruk. So ontstaan die gebruik in die Calvinistiese kerke in Europa om oor en weer mekaar se geloofsbelydenisse te aanvaar. So word die geloofsbelydenisse ook aangedui as formuliere van eenheid omdat dit die eenheid in die geloof verwoord het (Schaff 1919:394).

Die geloofsbelydenis het in die geloofsgemeenskap van die kerk ook gefunksioneer as aanduiding van die grense van die kerk. Hierdie aspek van die geloofsbelydenis het later, teen die bedoeling van Calvyn in, daartoe gelei dat die belydenisskrif as 'n maatstaf van die pura doctrina langs die Skrif gebruik is. Maar dan het die pura doctrina ook reeds weer 'n statiese begrip geword (Augustijn 1969:64-65). Uit die ontwikkeling het in Nederland in die negentiende eeu die Confessionele Beweging gegroei (Rasker 1974:253).

In ons tyd word daar oor die belydenisskrif en die waarde daarvan verskillend geoordeel. Die 'speelse' opmerking van Noordmans (1984:286) kan miskien hier in gedagte gehou word: 'Jezus zelf was confessioneel gebonden als niemand onzer. Hij had het hele Oude Testament achter zich en spelde, met iedere schrede die Hij deed, een van die oude teksten uit, tot op het kruis toe'. 
Die geloofsbelydenis bly tiperend van die geloof van die volk van God en die vashou aan die belydenisskrifte, tot die oudstes toe, is 'n teken nie net van die geloofseenheid van die kerk nie, maar ook van sy algemeenheid.

\section{DIE VOLK VAN GOD IN DIE WêRELD}

Samevattend kan gestel word dat volgens Calvyn die doel van die kerk daaruit bestaan dat dit ' $n$ instrument in die hand van God is waardeur die sondaarmens tot die geloof geroep word en waardeur die gelowiges versorg, gelei en gerig word in hulle strewe om in gehoorsaamheid aan God te lewe. Die prediking van die evangelie is daar om die geloof in Christus, deur die werk van die Heilige Gees, te wek en om die heiligmaking van die volk van God te bevorder deur 'n eenparige ineenstemming oor die geloof, die lewe van die gelowiges en die lewensorde van die kerk.

Dit is God wat sy volk versamel, bewaar en onderhou. Die kerk is dus anders as 'n vereniging wat vanuit die mens na vore kom en daar is om die kollektiewe wil van die lede te verwerklik. Die kerk is God se volk op pad na die voltooiing maar nie om die koninkryk van God te verwerklik nie. Die koninkryk is reeds daar, want dit staan aan die begin van die evangelie en nie aan die einde van die kerkgeskiedenis nie. Dit hoef nie meer opgerig te word nie, want van die opgestane en verhoogde Christus bely ons dat Hy na die hemel opgevaar het '... sodat Hy Homself daar as die Hoof van sy Christelike kerk kan betoon, deur wie die Vader alles regeer' (Heidelbergse Kategismus, Vraag en Antwoord Sondag 19).

Die kerk as die geloofsgemeenskap hoef Christus nie by te staan in enigiets nie en die enigste 'program' of 'missie' wat die kerk teenoor die wêreld het, is om deur die geloof in Christus te bestaan. Christus wil, deur sy kerk, in die wêreld werksaam wees. Die gevaar bestaan egter steeds dat die gelowiges die gevaar loop dat hulle met hulle bedrywighede in die wêreld Christus eerder hinder as help. Daarom is dit so belangrik dat die saak van kerk en wêreld vanuit die kerk bepaal word. As hierdie volgorde omgedraai word, ontkersten die kerk en word hy 'n nuttelose instrument in God se plan wat wil hê dat die wêreld kerk sal word.

Daarom sal dit vir die gelowiges van alle tye tog goed wees om nie die bekende gebed van Calvyn te vergeet nie. Dit lui, gedeeltelik, soos volg:

Aangesien $U$ ons nêrens anders rus belowe het nie as in $U$ hemelse koninkryk, daarom bid ons, almagtige God, dat ons op ons pelgrimsreis op aarde bereid sal wees om hier nie 'n blywende stad te hê nie maar om voort te snel terwyl ons $U$, ondanks dit alles, met volkome rustigheid in ons hart, aanroep. U het baie stryd vir ons beskik om ons daardeur te 
oefen en te beproef. Gee dat ons in hierdie stryd sal standhou en volhard totdat ons eindelik in daardie rus mag ingaan wat die bloed van $U$ eniggebore Seun vir ons verwerf het.

Amen.

\section{Literatuurverwysings}

Alting von Geusau, L G M 1963. Die Lehre von der Kindertaufe bei Calvin. Bilthoven: Uitgeverij $\mathrm{H}$ Nelissen.

Augustijn, C 1969. Kerk en belijdenis. Kampen: J H Kok.

Avis, P D L 1981. The church in the theology of the reformers. London: Marshall, Morgan \& Scott.

Baker, J W 1980. Heinrich Bullinger and the covenant. Athens: Ohio University Press.

Berkhof, H 1955. Geschiedenis der kerk. Nijkerk: G F Callenbach NV.

Bronkhorst, A J s a. Schrift en kerkorde, in Van 't Spijker, W (red), Inleiding tot de studie van het kerkrecht, 43-58. Kampen: J H Kok.

Burden, J S 1994. Teologiese opleiding in Suid-Afrika. HTS 50/1 \& 2, 111-139.

Calvinus, J 1559. Institutio christianae religionis, in Baum, G, Cunitz, E, Reuss, E (eds), 1863-1900: Ioannis Calvini opera quae supersunt omnia. Brunsvigae: G A Schwetschke et filium. (Aangehaal as CO.)

Graafland, C 1989. Kinderen van een moeder. Kampen: J H Kok.

Jacobs, P 1959. Theologie Reformierten Bekenntnisschriften in Grundzügen. Neukirchen Kreis Moers: Neukirchener Verlag.

Luther, M Kritische Gesamtausgabe. Weimar: Hermann Bölhaus Nachfolger. (Aangehaal as WA.)

Milner, B C 1970. Calvin's doctrine of the church. Leiden: E J Brill.

Niesel, W 1938. Bekenntnisschriften und Kirchenordnungen der nach Gottes Wort reformierten Kirche. Zollikon-Zürich: Evangelischer Verlag AG.

Noordmans, O 1984. Verzamelde werken, Deel V. Kampen: J H Kok.

Oberman, H A 1988. De erfenis van Calvijn. Kampen: J H Kok.

Parker, T H L 1975. John Calvin: A biography. London: J M Dent \& Sons Ltd.

Pont, A D 1981. Die historiese agtergronde van ons kerklike reg, Deel 1. Pretoria: HAUM.

- 1991. Confession of faith in Calvin's Geneva, Van 't Spijker, W (red), Calvin, Erbe und Auftrag, 106-116. Kampen: Kok Pharos.

Rasker, A J 1974. De Nederlandsche Hervormde Kerk vanaf 1795. Kampen: J H Kok. 
Schaff, P 1919. The creeds of Christendom. New York \& London: Harper.

Schwarz, R 1962. Johannes Calvins Lebenswerk in seinen Briefen. Neukirchen Kreis Moers: Neukirchener Verlag.

Simpson, H W 1980. Onderwysing in die Christelike godsdiens deur Johannes Calvyn 1536. Potchefstroom: CJBF.

- 1981. Calvyn se Kategismus. Potchefstroom: PTK.

- 1991. Institusie van die Christelike godsdiens deur die skrywer Johannes Calvyn 1559. Potchefstroom: CJBF.

Van 't Spijker, W 1970. De ambten bij Martin Bucer. Kampen: J H Kok.

Wendel, F 1978. Calvin, translated by P Mairet. London: William Collins Sons \& Co Ltd. 